\title{
CORPORATE SOCIAL RESPONSIBILITY: \\ THE FINANCIAL IMPACT OF BLACK ECONOMIC \\ EMPOWERMENT transaCtions in SOUTh Africa
}

Hendrik Wolmarans

School of Financial Management, University of Pretoria

Kurt Sartorius

School of Accountancy, University of the Witwatersrand

\begin{abstract}
Corporate social responsibility (CSR) has recently received considerable attention in literature. One of the vehicles by which companies can conform to CSR in South Africa is Black Economic Empowerment (BEE). In this regard, BEE has been employed to assist previously disadvantaged groups of investors obtain a larger share of the equity of South African listed companies. The question has often been asked whether the announcement of BEE transactions by listed companies increases shareholder wealth. This article tries to answer this question by examining the share performance of 125 BEE transactions involving 95 companies during the period January 2002 to July 2006. The results indicate a positive relation between BEE transaction announcements and shareholder wealth creation, but only during the last part of the period covered by the study.
\end{abstract}

Abstract

JEL D64, G14, M14

\section{1 \\ Introduction}

Since apartheid was abolished with the first democratic election in South Africa in 1994, companies have been encouraged to increase the participation of the black majority population in economic wealth creating activities. Various programmes focused on the redistribution of wealth include privatisation, affirmative action, amended fiscal and monetary policy and the introduction of Black Economic Empowerment (BEE) as a cornerstone of economic policy (Gevisser, 1997; Bratton, 1998; Engdahl \& Hauki, 2001; Jackson, Alessandri \& Black, 2005). $\mathrm{BEE}$, in particular, has become increasingly popular in facilitating an increase in corporate ownership by black investors. In this regard, many firms have demonstrated their Corporate Social Responsibility (CSR) by selling part of their equity to black empowerment groups. BEE has been justified on an equity basis, as well as for economic reasons and giving previously disempowered people better access to markets and institutions may enable them to acquire additional human capital, a condition necessary for continued sustainable economic growth (Black, 2002:1160).

The growth of BEE has unfolded in a number of phases. The first phase that occurred during 1996-1998, saw market capitalisation increase from 0.7 percent to 6 percent of the Johannesburg Stock Exchange (JSE) South Africa (Engdahl \& Hauki, 2001:2). This sudden foray into capitalism was arrested by the market crisis of 1998 that witnessed a reduction in BEE ownership from 7 percent to 2.2 percent largely because of a major drop in heavily leveraged BEE acquired companies' share prices (Southall, 2004:318; Beall, Gelb \& Hassim, 2005:693). Emerging from this first phase of BEE, some economic realities surfaced and black ownership climbed back to an estimated 4 percent by 2004 . This second phase has been described as more 
meaningful and cognizant of the market realities of risk versus return (Engdahl \& Hauki, 2001). With the introduction of the Broad Based Black Economic Empowerment Act in 2003 (BBBEE), the emphasis on equity transfers in BEE compliance has been reduced, but equity transfer remains a significant component at 20 percent of the overall Broad Based BEE Balanced Scorecard rating.

Ten years later the jury is still out with respect to the success or failure of BEE. On the one hand, ownership of capital on the JSE has increased to 4 percent with a swathe of industry charters promoting BEE in the various sectors (Southall, 2004; Thompson, 2004). In addition, there has been a sustained growth of a black middle class since 1994 (Burger \& Van den Berg, 2004) and stateowned enterprises have vigorously promoted both preferential procurement programmes, as well as transformation of their ownership and management structures (Southall, 2004; 2005). Conversely, many critics suggest that BEE is a sham, that it has only benefited the politically connected elite and that it is a front for maintaining the historic demographics of ownership (Engdahl \& Hauki, 2001; Mazibuko \& Boshoff, 2003; Southall, 2004; 2005; Freund, 2006). Finally, there are claims that BEE deters foreign investment (Thompson, 2004; Southall, 2004; 2005; Butler, 2006) and that the transfer of ownership to BEE partners could tie up R450 billion (Cargill, 2005:21)

This study investigates the share performance of companies listed on the JSE and involved in BEE transactions, specifically in terms of its ability to create shareholder wealth. The importance of the study is underlined by the growing frustration of the marginalised (Engdahl \& Hauki, 2001), the escalating ambivalence of Cosatu with respect to BEE (Southall, 2004) and the fear that if the next phase of BEE is not successful, that the consequences could be disturbing (Butler, 2006:14). This study confines itself to the equity ownership dimension of BEE and does not investigate the other aspects of the BEE scorecard.

The study develops as follows: Section One is the introduction. Section Two sets out the research questions. Section Three reviews both the CSR and event study literature. Section Four outlines the research design. Section Five develops the empirical results. Section Six discusses the limitations of the study and identifies areas for future research. Finally, Section Seven concludes the study.

\section{2}

\section{Research questions}

The research questions addressed in this study are the following:

1. Are announcements of BEE transactions related to shareholder value creation?

2. Do the announcements of different types of BEE transactions lead to differences in shareholder wealth creation?

3. Do different years lead to differences in shareholder wealth creation when BEE transactions are announced?

In this study the cumulative abnormal returns (CAR) of share prices are used as a proxy for shareholder value creation and the event study methodology is used.

\section{3}

\section{Literature survey}

\subsection{Corporate social responsibility}

\subsubsection{The definition and importance of corporate social responsibility}

There is growing evidence that market participants care - or at least should care - about CSR (Boutin-Dufresne \& Savaria, 2004:64). CSR has been widely studied in the literature. McWilliams, Siegel and Wright (2006:1) define CSR as a situation where the firm goes beyond compliance and engages in actions that appear to further some social good, beyond the interests of the firm and that which is required by law. Siegel and Vitaliano (2007:773) agree that CSR occurs when firms appear to advance a social agenda beyond that which is required by rules and regulations. For instance, if a savings and loan institution approves a higher proportion of loans to poor and minority borrowers than that required by the relevant regulations, this 
institution is said to be socially responsible. Frederick (1994:150) outlines a conceptual transition from $\mathrm{CSR}_{1}$ to $\mathrm{CSR}_{2}$, which he defines as the transition in business and society scholarship from the philosophical-ethical concept of social responsibility (corporations' obligation to work for social betterment) to the action-oriented managerial concept of corporate responsiveness (the capacity of a corporation to respond to social pressure). After a bibliometric analysis of 30 years of research and theory on corporate social responsibility, De Bakker, Groenewegen and Den Hond (2005:312) come to the conclusion that the field of CSR has become firmly embedded in the management sciences.

Munilla and Miles (2005:371) see CSR as an important component of stakeholder theory. If a company engages in CSR activities and proves that it is socially responsible, this may contribute to its main goal of creating shareholder wealth over the long term. Other authors have recently found that CSR plays a key role in economic and social development (Galan, 2006:1640), that research in CSR is driven by interests in the business environment as well as continuing scientific engagement (Lockett, Moon \& Visser, 2006:115), and that CSR requires a fine balance between social responsibility and responsibility towards the shareholders of a company (Windsor, 2006:93). Siegel and Vitaliano (2007:774) even define "profit maximising" CSR as a situation when firms engage in socially responsible actions because they anticipate certain intangible benefits from these actions. Examples of such actions include reputation enhancement, the ability to charge a premium price for their output, or the use of CSR to recruit and retain high quality workers. These benefits are presumed to offset the higher costs associated with CSR, because the resources that must be allocated to allow the firm to achieve CSR status are often expensive. Finally, messages about corporate ethical and socially responsible initiatives will most likely evoke strong and often positive reactions among stakeholders (Morsing \& Schultz, 2006:323). These researchers also point out that there are potential business benefits of the internal and external communication of CSR efforts.
Shareholders appear to view CSR in a positive light (Waddock \& Graves, 1997:303; Galan, 2006:1640; Munilla \& Miles, 2005:371) and BEE, from an efficiency perspective, may enhance wealth because it could be a strategic opportunity to grow market share (Koollen, 2004; Woolley, 2005). Finally, BEE acts as a strategy to integrate South Africa into the global arena, it stimulates human resource development and promotes the firm's social and economic contacts (Engdahl \& Hauki, 2001; Jackson et al., 2005).

\subsubsection{Popular issues related to CSR}

Lockett et al. (2006:115) investigated the focus, nature and salience of CSR when they reviewed CSR-related research published in the management literature during the decade from 1992 to 2002. Their results demonstrate that the most popular issues related to CSR that have been investigated pertain to environmental and ethical implications. Empirical research carried out has been overwhelmingly of a quantitative nature and the field is driven by interests in the business environment as well as continuing scientific engagement. Windsor (2006:93) posits that three key approaches to CSR should be kept in mind. Firstly, ethical responsibility theory advocates strong corporate self-restraint and altruism duties and expansive public policy strengthening stakeholder rights. Secondly, economic responsibility theory advocates market wealth creation, subject only to minimalist public policy and, perhaps, customary business ethics. Thirdly, corporate citizenship language invokes a political metaphor providing neither true intermediate positioning nor theoretical synthesis, but expands philanthropy as a strategic lever for increasing corporate reputation and market opportunities.

\subsubsection{Financial performance and CSR}

Empirical tests of whether CSR companies have higher rates of return have produced mixed results. Some researchers found a positive correlation, others found no correlation, while a third group tried to explain why correlations may vary. Boutin-Dufresne and Savaria (2004:57) point out that the value of the socially screened portfolios in the US has grown by 240 percent 
between 1995 and 2003, 40 percent faster than all professionally managed assets. In 2003 there were as many as 200 mutual funds which were managed according to strong ethical guidelines, versus only 55 in 1995 . This reflects a significant increase in investment demand for CSR companies' shares, which is positive for CSR. McGuire, Sundgren and Schneeweis (1988:854) found a positive relationship between CSR and financial performance. McWilliams and Siegel (1997a:98) found that when money market managers took into account the CSR in the companies that they invested in, this improved their risk assessment. Waddock and Graves (1997:303) found that CSR is positively related to prior financial performance, but also to future financial performance. Orlitzky, Schmidt and Rynes (2003:403) conducted a meta-analysis of 52 previous studies on the relationship between CSR and corporate financial performance (CFP) and found this relationship to be positive.

A second group of researchers found no positive correlation between CSR and CFP. Aupperle, Carroll and Hatfield (1985:446) found no relationship between varying levels of social orientation and financial performance. Guerard (1997:11) found no significant difference between the average returns of a socially screened universe $(\mathrm{N}=950)$ and an unscreened universe $(\mathrm{N}=1300)$ for the period 1987 to 1994. McWilliams and Siegel (2000:603) found that CSR had a neutral impact on financial performance.

One of the third group of researchers is Barnett (2007:794) who tried to explain why the effects of CSR on CFP vary across firms and time, and developed a set of propositions to aid future research on the contingencies that produce variable financial returns to investment in CSR. Barnett and Salomon (2003:386) hold the view that firms are not inherently good or bad. Rather, they are profitseeking, and will engage in those behaviours that they expect to increase their shareholders' value. CSR research thus best functions as a means of helping firms and investors identify what the market wants. Campbell (2007:946), however, argues that the relationship between financial performance and corporate social behaviour is mediated by several institutional conditions. These include public and private regulations, the presence of non-governmental and other independent organisations that monitor corporate behaviour and institutional norms regarding appropriate corporate behaviour. Other conditions include associative behaviour amongst corporations themselves and organised dialogues between corporations and their stakeholders. Whether more CSR leads to better financial performance is thus not an easy question to answer.

\subsubsection{CSR and investing in South Africa}

The issue of CSR and its influence on international investment in South Africa has been contested by various researchers. Teoh, Welch and Wazzan (1999:35) studied what they regarded as one of the most important legislative and shareholder boycotts to date, namely the boycott of South Africa's apartheid regime (as an example of CSR). They found that corporate involvement with South Africa was so small that the announcement of legislative/shareholder pressure or voluntary corporate divestment from South Africa had little discernible effect either on the valuation of banks and other corporations with South African operations, or on the South African financial markets. Wright and Ferris (1997:77) examined the effect on firm value of divestment from South Africa by US publicly-traded firms. Their results indicate that significant and negative excess returns accrued to shares of companies announcing divestments from South Africa, supporting the premise that noneconomic pressures may influence managerial strategies rather than value-enhancement goals. However, Posnikoff (1997:76) found that multinational corporations that withdrew investments from South Africa at a time when this country had a socially undesirable political system were positively evaluated by international investors.

From this sub-section it is clear that the relationship between CSR and CFP has been widely studied and debated in the literature. In the next sub-section the methodology of event studies, the research technique used in this study, will be touched upon. 


\subsection{Event studies}

\subsubsection{Event study methodology}

Event studies have been widely used in the financial literature to determine the impact of announcements (for example, of CSR transactions) and other actions by top management on the share prices of their companies. Since Fama, Fisher, Jensen and Roll (1969:1) pioneered the well-known event study methodology, many researchers have used this method of enquiry. The impact of an event on the value of a firm's common stock is usually assessed by measuring the difference between the actual and expected returns on the stock during a relevant period surrounding the event. Woolridge and Snow (1990:357) call this approach the market-adjusted returns approach; Brown and Warner (1985:3) show that this approach is as powerful as other more restrictive models of expected stock returns in detecting significant stock price movements associated with specific events.

The event study method has become popular because it obviates the need to analyse accounting-based measures of profit, which have been criticised because these measures are often not very good indicators of the true performance of firms. Managers can, for example, manipulate accounting profits by selecting different accounting procedures. McWilliams and Siegel (1997b:652) outline ten steps for implementing an event study in a comprehensive procedure based on the work of Brown and Warner (1985:3). Many researchers have used this methodology and have had positive experiences of it. Others have some reservations concerning this methodology and still others point out that researchers should beware of the method's implicit limitations.

\subsubsection{Positive experiences of event studies}

McWilliams and Siegel (1997b:626) found the event study method to be a powerful tool that can help researchers assess the financial impact of changes in corporate policy. Using this method, a researcher can determine whether there is an "abnormal" share price effect associated with an unanticipated event. From this the researcher can determine the significance of the event. This method has been used extensively in studying the financial implications of CSR activities. Examples of these studies are: awards for affirmative action programmes (Wright, Ferris, Hiller \& Kroll, 1995:272), withdrawal of investments from South Africa (Meznar, Nigh \& Kwok, 1994:1663, Posnikoff, 1997:76), plant closings (Clinebell \& Clinebell, 1994:553), product recall announcements (Davidson \& Worrell, 1992:467), major layoff programmes (Worrell, Davidson \& Sharma, 1991:662) and corporate illegalities (Davidson \& Worrell, 1988:195).

Brown and Warner (1980:205) found that a simple methodology based on the market model is both well-specified and relatively powerful under a wide variety of conditions. Brown and Warner (1985:3) added to this by examining properties of daily stock returns thus concluding that daily data generally present few difficulties for event studies. Bromiley, Govekar and Marcus (1988:37) found the extension of finance theory in event studies related to shareholder wealth an extremely valuable tool. But, as with most complex tools and particularly those that are still evolving, correct use of this method of enquiry is dependent on a sophisticated understanding of both theory and practice.

\subsubsection{Reservations concerning event study methodology}

Criticisms have been raised against the use of event studies. McWilliams and Siegel (1997b:626) evaluated the use of the event study methodology to measure the consequences of CSR activities. In a large number of events studies of CSR appearing in top management journals, the authors found the conclusions unreliable due to what they regard as serious flaws in the research design and implementation of the event study methodology. McWilliams, Siegel and Teoh (1999:340) also caution that an analysis of only share price effects relates to financial stakeholders, whereas analysts should keep in mind that non-financial stakeholders are also affected by CSR activities.

Kramer (2001:109) points out that various test statistics have been employed in the finance and accounting literature for the purpose of conducting hypothesis testing in 
event studies. However, these statistics do not always follow their conventionally assumed asymptotic distributions, even for large samples of firms. The approach of Fama et al. (1969:1) assumes that the residuals are independent and identically distributed. However, these assumptions can be challenged due to various reasons. Firstly, the abnormal returns - the expectations of the residuals - are likely to differ across firms. Secondly, the residual variance may differ across firms. Finally, the residuals will not be independent if the event occurs during the same calendar period for some firms and these firms are in the same or related industries. Binder (1985:370) proposes a multivariate regression model to overcome at least some of the criticisms above. Kramer (2001:109) suggests a simple normalisation of the conventional test statistic with bootstrap re-sampling to overcome these criticisms. Dombrow, Rodriques and Sirmans (2000:361) even suggest a nonparametric approach to event studies.

\subsubsection{Researchers should be aware of certain aspects when using event studies}

Some researchers have pointed out aspects to beware of when using event studies. McWilliams and Siegel (1997b:626) studied 29 event studies in three top management journals and identified the event window as possibly the most crucial research design issue in an event study. The event window should be long enough to capture the significant effect of the event, but short enough to exclude any confounding effects. Salinger (1992:671) notes that cumulative abnormal returns do not accurately measure the effect of an event on firm value if there are dividends during the event window. In event studies of emerging stock markets, Bhattacharya, Daouk, Jorgenson and Kehr (2000:69) warn that occurrences such as unrestricted insider trading may cause prices to fully incorporate the information relevant to the event even before the public release of that information.

Finally, in spite of many criticisms and caveats, from this sub-section it is clear that event studies have much potential when studying the impact of CSR activities on share performance. In the following sub-section the research design which was used in this study is explained.

\section{4 \\ Research design}

In this study an event study methodology is used to calculate the cumulative abnormal returns (CAR) associated with the public announcement of 125 BEE transactions involving 95 companies between January 2002 and July 2006 (see Appendix 1).

Although a small number of companies had more than one BEE transaction during this period, these were assumed to be independent for the sake of this study. The data obtained from BusinessMap (2007) was reviewed, and no indication was found to indicate significant dependence.

The standard approach to an event study is based on estimating a market-related return for a specific company, and then calculating abnormal returns for a certain number of days before and after the event that is studied. These abnormal returns are assumed to reflect the stock market's reaction to the arrival of the new information pertaining to the event. The following method was used by McWilliams and Siegel (1997b:628), Reuer (2000:8) and Jackson et al. (2005:14). The rate of return for the share of firm $i$ on day $t$ is expressed as:

$\mathrm{R}_{i t}=\alpha_{i}+\beta_{i} \mathrm{R}_{m t}+\varepsilon_{i t}$,

where

$\mathrm{R}_{i t}=$ the return on share $i$ on day $t$;

$\mathrm{R}_{m t}=$ the return on a market portfolio on day $t$, such as the All-Shares Index on the JSE Securities Exchange;

$\alpha_{i}=$ the intercept term for share $i$;

$\beta_{i}=$ the systematic risk of share $i$; and

$\varepsilon_{i t}=$ the error term, where $\mathrm{E}\left(\varepsilon_{i t}\right)=0$.

From an estimation of the equation above, one could calculate daily abnormal returns $\left(\mathrm{AR}_{i t}\right)$, over and above those returns which are associated with the return on the market, for firm $i$ on day $t$ by using the following equation:

$\mathrm{AR}_{i t}=\mathrm{R}_{i t}-\left(\mathrm{a}_{i}+\mathrm{b}_{i} \mathrm{R}_{m t}\right)$

where

$\mathrm{AR}_{i t}=$ the abnormal return of firm $i$ on day $t$; 
$\mathrm{R}_{i t}=$ the observed return of firm $i$ on day $t$; and

$\left(\mathrm{a}_{i}+\mathrm{b}_{i t} \mathrm{R}_{m t}\right)=$ firm $i$ 's forecast return on day $t$, based on the market return.

The forecast return is constructed from the firm-specific parameters $\mathrm{a}_{i}$ and $\mathrm{b}_{i}$ obtained from equation (1) by way of the ordinary least squares method, as well as the actual market return $\left(\mathrm{R}_{m t}\right)$ obtained on day $t$. Usually the estimation period is from 250 to 50 days prior to the event.

The abnormal returns (AR) thus represent returns earned by the firm after adjusting for the "normal" or market-related returns, in other words after subtracting the expected return from the actual return. The CAR can then be calculated for a firm as the sum of the AR terms over the period in question, for example three or five days. The approach followed by McWilliams and Siegel (1997b:647) as well as Jackson et al. (2005:14) includes calculating the CAR for four different periods. These periods entail different measures which are relevant in the event study, as indicated in Table 1.

Table 1

Measures of CAR for different periods surrounding an event

\begin{tabular}{|c|c|}
\hline Days relative to the event & Measure of cumulative abnormal return \\
\hline-20 to -3 & R1 \\
\hline-2 to +2 & R2 \\
\hline-1 to +1 & R3 \\
\hline+3 to +20 & R4 \\
\hline
\end{tabular}

In line with Jackson et al. (2005:15) both a fiveday window (measure R2 for days -2 to +2 ) and a three-day event window (measure R3 for days -1 to +1 ) are used here. What one would expect if $\mathrm{BEE}$ events did indeed lead to a positive effect on share price for a reasonable sample of firms is that the average values of both R2 and R3 would be significantly positive. In addition, the average values of R1 and R4 would not differ significantly from zero.

\section{5}

\section{Empirical results}

\subsection{Abnormal returns and BEE events}

The first research question of this study asks whether announcements of BEE transactions are related to shareholder value creation. Positive abnormal returns are regarded, in this study, as an indication of shareholder wealth creation. In order to answer this question a list of the dates of announcements of BEE transactions between 2002 and 2006 involving companies listed on the JSE was obtained from BusinessMap (2007), a company specialising in black empowerment data. The public announcement date of a BEE transaction involving a company was then regarded as day zero $(0)$ of that transaction. If the announcement was made over a weekend, the first trading day thereafter was taken as day zero.

The study used the BFA-Net database at the University of Pretoria to obtain the necessary daily share prices. Each company's daily share prices were obtained from day -250 to day +20 relative to the $\mathrm{BEE}$ transaction, as well as the value of the market index for the same number of days. Subsequently, for each company, estimates $\mathrm{a}$ and $\mathrm{b}$ were determined for the parameters $\alpha$ and $\beta$ in equation (1). These were then used with equation (2) to determine the expected returns for days -20 to +20 relative to the event, the abnormal returns for each of these days, and finally R1, R2, R3 and R4, which are measures of CAR as indicated in Table 1.

The average values for $\mathrm{R} 1$ to $\mathrm{R} 4$ were calculated for the 125 transactions involved, and then T-tests were performed to determine if these measures were on average significantly different from zero. The results are given in Table 2 . 


\section{Table 2}

The average values of CAR for different windows relative to the announcement of 125 BEE transactions

\begin{tabular}{|c|c|c|c|c|c|}
\hline Variable & N & Average & Std.Dev. & T-value & p-value \\
\hline R1 & 125 & -0.0114 & 0.1393 & -0.9150 & 0.1810 \\
\hline R2 & 125 & 0.0091 & 0.0937 & 1.0858 & 0.1398 \\
\hline R3 & 125 & 0.0115 & 0.0611 & 2.1043 & 0.0187 \\
\hline R4 & 125 & -0.0001 & 0.1114 & -0.0391 & 0.4844 \\
\hline
\end{tabular}

From Table 2 it is clear that, on average, there was a significantly positive average abnormal return of 1.15 percent for the event window from day -1 to day +1 (measure R3). Taking the standard deviation and the sample size into account, the associated T-value is 2.1043 . For a one-sided test of whether this measure is significantly positive, a p-value of 0.0187 was found with the function TDIST on an Excel spreadsheet. Because this pvalue is less than 0.05 , one can conclude that the average return for the event window from day -1 to day +1 was significantly positive. A similar $\mathrm{p}$ value for measure $\mathrm{R} 2$ (for the event window from day -2 to day +2 ), that is, smaller than 0.05 , would have confirmed the fact that a BEE transaction is associated with a significant increase in share price, but this was not the case. The relatively large $\mathrm{p}$-value for $\mathrm{R} 2$ of 0.1398 indicates that this measure is not significantly positive. Similarly, a one-sided test for the averages of R1 and R4 indicates that these measures are not significantly positive. A two-sided test would have given double these p-values, confirming the nonsignificance of these values.

The results from this sub-section indicate that an average significant abnormal return over a three day window was found for the 125 BEE transactions. This then answers the first research question.

\subsection{The impact of types of BEE transactions and years}

The second research question asks whether the announcements of different types of BEE transactions lead to differences in shareholder wealth creation. The third research question is whether different years lead to differences in shareholder wealth creation when BEE transactions are announced. In order to answer these questions, an analysis of variance (ANOVA) was performed on each of the four measures $\mathrm{R} 1$ to R4. In each case the impact of the year (2002 to 2006) and the type of transaction were investigated. The different types of transactions were identified as:

1) the selling of equity to a BEE company;

2) the purchasing of a stake in a BEE company; and

3) other BEE transactions like involvement in partnerships or joint ventures.

The p-values associated with the results of the ANOVA performed on each of the measures $\mathrm{R} 1, \mathrm{R} 2, \mathrm{R} 3$ and R4 to determine whether year or type of transaction contributed to explaining the variance, are given in Table 3.

\section{Table 3}

The p-values resulting from the ANOVA on each of the measures R1, R2, R3 and R4 to

determine the impact of Year and Type

\begin{tabular}{|c|c|}
\hline Measure & p-value \\
\hline R1 & 0.9713 \\
R2 & 0.2474 \\
R3 & 0.0256 \\
R4 & 0.5902 \\
\hline
\end{tabular}

Table 3 shows that only measure $\mathrm{R} 3$ seems to be significantly affected by changes to announcement year and BEE transaction type. These factors do not seem to contribute to explaining the variance of the abnormal returns for the other three measures. The output from the ANOVA performed on measure $\mathrm{R} 3$ is given in Table 4. 


\section{Table 4}

ANOVA on measure R3 to determine the impact of Year and Type on CAR associated with BEE transactions

\begin{tabular}{|l|c|c|c|c|c|}
\hline \multicolumn{1}{|c|}{ Source } & d.o.f. & Sum of squares & Mean square & F-value & $\operatorname{Pr}>\mathbf{F}(\mathbf{p}$-value) \\
\hline Year & 4 & 0.03776 & 0.00944 & 2.71 & 0.0332 \\
\hline Type & 2 & 0.01454 & 0.00727 & 2.09 & 0.1284 \\
\hline Model & 6 & 0.05229 & 0.00872 & 2.51 & 0.0256 \\
\hline Error & 118 & 0.41052 & 0.00348 & & \\
\hline Corrected total & 124 & 0.46281 & & & \\
\hline
\end{tabular}

It can clearly been seen in Table 4 that the year of announcement had a significant effect on the CAR. The type of transaction had no impact on explaining the differences between CARs. Stated differently, different types of BEE transactions had no impact on the creation of wealth. This answers the second research question.
The third research question addresses the question of whether abnormal returns differed between years. One could extend this question: If there are differences (as indicated by Table 4 ), where are these? In order to answer this question, the average values for measures R1 to R4 have been calculated for each of the years 2002 to 2006, as indicated in Table 5.

Table 5

Average values for measures R1 to R4 for each of the years 2002 to 2006

\begin{tabular}{|c|c|c|c|c|c|}
\hline Years & No. events & R1 & R2 & R3 & R4 \\
\hline 2002 & 10 & -0.0020 & 0.0034 & 0.0158 & -0.0278 \\
\hline 2003 & 13 & -0.0092 & 0.0073 & -0.0005 & 0.0192 \\
\hline 2004 & 27 & 0.0157 & 0.0029 & 0.0066 & -0.0253 \\
\hline 2005 & 42 & -0.0263 & -0.0133 & -0.0048 & 0.0218 \\
\hline 2006 & 33 & -0.0148 & $0.0448^{* *}$ & $0.0386^{* * *}$ & -0.0055 \\
\hline Total & 125 & & & & \\
\hline
\end{tabular}

** significant at $5 \%$ level

*** significant at $1 \%$ level

From Table 5 it is clear that measures R2 and $\mathrm{R} 3$ had significantly positive average values of respectively 4.48 percent and 3.86 percent for the year 2006. However, for none of the years 2002 to 2005 did these measures have significant positive values. Measures R1 and R4 had no significant values for any of the years.

\section{6}

\section{Limitations of this study and areas for further research}

Although BEE is important for South African companies to give expression to their CSR objectives, data on BEE transactions are not widely available. This limits the type of research that is possible on this important topic. This study did not, for example, investigate the impact of the specific values of the transactions and 
their relationship to shareholder value. Future research should address this relationship.

In this study a single market index was used when calculating abnormal returns at the time of the announcement of BEE transactions. As is evident from Appendix 1, not only were industrial companies involved, but also financial and resource companies. If future research would perhaps use different, more focused indices for these different types of companies, different CAR values would perhaps lead to different results.

During the whole period covered by the study, the JSE was in an upward trend. Recently, however, a global financial crisis has lead to sharp decreases in international share prices. Future research could address the question of whether companies that have engaged in BEE transactions behave differently under recessionary economic circumstances (in terms of value created relative to the market) than during periods of growth in the economy.

This study focuses on the equity ownership dimension of BEE and does not investigate the other aspects of the BEE scorecard. Naturally, a comprehensive study on the impact of BEE should also take these aspects into account.

It could be argued that the companies in the study participated in BEE activities only due to their desire to score points on their BEE scorecards, and not due to any feelings of social responsibility. It may, in fact, be difficult to determine the true motivations of companies that have acted in a seemingly socially responsible manner. Future research could address this issue.

This study addresses the short-term relationship between a BEE announcement and shareholder value. The medium- and long-term relationships were not investigated. Are the increases in shareholder value created through BEE transactions sustainable over the long-term? This is certainly an important area for further research. CSR is especially important for a country like South Africa where a large part of the population was, for many years, excluded from many valuecreating opportunities in the economy. This justifies the notion that much more research is needed in terms of the value created for various stakeholders in BEE transactions.

\section{Conclusion}

A BEE transaction is an important vehicle whereby South African companies can give expression to their CSR objectives. In this study, the short-term financial impact of 125 BEE transactions involving 95 companies is studied. The most important conclusion is most probably the significant positive average return of 1.15 percent found for the three day event window (measure R3) surrounding a BEE announcement. It is safe to state, therefore, that BEE announcements seem to have a positive impact on shareholder wealth.

The results also indicate that there are no significant positive differences on the effect on shareholder wealth creation between different types of BEE transactions. There were, however, differences in the impact on value creation when the different years of announcements were considered. Surprisingly, the announcement of BEE transactions between 2002 and 2005 had no significantly positive impact on shareholder value creation, but for 2006 it had a significantly positive impact over both the three-day and the five-day windows. Although previous research found highly significant results from BEE announcements for the years 1996 to 1998, the results from this study are not as exciting for the period 2002 to 2006. The reason could be that BEE transactions were still new during the years 1996 to 1998, and investors may have had high expectations of companies that engaged in them. Many investors during this period may have been more interested in acquisitions than the actual creation of wealth. The market crisis of 1998, however, resulted in a significant drop in BEE ownership largely as a result of heavily leveraged BEE shares.

During the period 2002 to 2005, investors may have, therefore, become more exposed to the economic realities of BEE transactions, and more cautious in their evaluation of only the announcements of these transactions. It could of course also be true that the BEE activities of previous years had led to a change in the profile of the average shareholder, and therefore also the shareholder's view of the announcements. Why this changed view was only reflected in the year 2006 is not clear. 
The results of this study could be important for developing countries. Investors who may at first be excited about BEE transactions as a way of fulfilling shareholder wishes for the company to engage in CSR, may later become disillusioned with this type of corporate activity. However, the positive results of the $\mathrm{BEE}$ announcements during the last year under consideration raise a question. Why were there positive share price movements during only 2006, while investors seemed to have been lethargic towards BEE announcements during the period 2002 to 2005 ?

In this study a positive relationship between corporate social responsibility and share value creation was found. This leads to a better understanding of how investors view the announcement of BEE transactions and opens the door for further research of this important topic.

\section{8}

\section{References}

AUPPERLE, K.E., CARROLL, A.B. \& HATFIELD, J.D., 1985. An empirical examination of the relationship between corporate social responsibility and profitability. Academy of Management Journal, 28(2): 446-463.

BARNETT, M.L., 2007. Stakeholder influence capacity and the variability of financial returns to corporate social responsibility. Academy of Management Review, 32(3): 794-816.

BARNETT, M.L. \& SALOMON, R.M., 2003.

Throwing a curve at socially responsible investing research. Organization and Environment, 16(3): 381389.

BEALL, J., GELB, S. \& HASSIM, S., 2005. Fragile stability. Journal of Southern African Studies, 31(4): 681-700.

BHATTACHARYA, U., DAOUK, H., JORGENSON, B. \& KEHR, C.H., 2000. When an event is not an event: the curious case of an emerging market. Journal of Financial Economics, 55(1): 69-101.

BINDER, J.J., 1985. On the use of the multivariate regression model in event studies. Journal of Accounting Research, 23(1): 370-383.

BLACK, P.A., 2002. On the case for 'Black economic empowerment' in South Africa. The South African Journal of Economics, 70(8): 1148-1162. BOUTIN-DUFRESNE, F. \& SAVARIA, P., 2004. Corporate social responsibility and financial risk, The
Journal of Investing, 13(1): 57-66.

BRATTON, M., 1998. After Mandela's miracle in

South Africa. Current History, May: 214-219.

BROMILEY, P., GOVEKAR, M. \& MARCUS, A., 1988. On using event-study methodology in strategic management research. Technovation, 8(1): 25-40. BROWN, S.J. \& WARNER, J.B., 1980. Measuring security price performance. Journal of Financial Economics, 8(1): 205-258.

BROWN, S.J. \& WARNER, J.B., 1985. Using daily stock returns: the case of event studies. Journal of Financial Economics, 14(1): 3-31.

BURGER, R. \& VAN DEN BERG, S., 2004.

Emergent black affluence and social mobility in postapartheid South Africa. Development Policy Research Unit, Working Paper 04/87, University of Stellenbosch. BUSINESSMAP., 2007. Black economic empowerment transactions in South Africa [Online]. Available at: http://www.bmap.co.za [Accessed 20 July 2007]. BUTLER, A., 2006. Black economic empowerment. Working Paper, University of Cape Town.

CAMPBELL, J.L., 2007. Why would corporations behave in socially responsible ways? An institutional theory of corporate social responsibility. Academy of Management Review, 32(3): 946-967.

CARGILL, J., 2005. Black corporate ownership: complex codes can impede change. in S Brown (ed), Conflict and Governance: Economic Transformation Audit 2005 (pp. 21-27 ), Cape Town: Institute for Justice and Reconciliation.

CLINEBELL, S.K. \& CLINEBELL, J.M., 1994. The effect of advanced notice of plant closings on firm value. Journal of Management, 20(3): 553-564.

DAVIDSON, W. \& WORRELL, D., 1988. The impact of announcements of corporate illegalities on shareholder returns. Academy of Management Journal, 31(1): 195-200.

DAVIDSON, W. \& WORRELL, D., 1992. The effect of product recall announcements on shareholder wealth. Strategic Management Journal, 13(6): 467-473. DE BAKKER, F.G.A., GROENEWEGEN, P. \& DEN HOND, F., 2005. A bibliometric analysis of 30 years of research and theory on corporate social responsibility and corporate social performance. Business and Society, 44(3): 283-317.

DOMBROW, J., RODRIQUES, M. \& SIRMANS, C.F., 2000. A complete nonparametric event study approach. Review of Quantitative Finance and Accounting, 14(4): 361-380.

ENGDAHL, C. \& HAUKI, H., 2001. Black Economic Empowerment: An Introduction for Non-South African Businesses. Masters Thesis: Gothenburg University. FAMA, E.F., FISHER, L., JENSEN, M.C. \& ROLL, R., 1969. The adjustment of stock prices to new 
information. International Economic Review, 10(1): $1-21$.

FREDERICK, W.C., 1994. From CSR 1 to CSR 2 . Business and Society, 33(2): 150-164.

FREUND, B., 2006. State, capital and the emergence of a new power elite in South Africa: black economic empowerment at national and local levels. Paper presented during Session 86 of the XIV International Economic History Congress, 15 July, Helsinki.

GALAN, J.I., 2006. Corporate social responsibility and strategic management. Journal of Management Studies, 43(7): 1629-1640.

GEVISSER, M., 1997. Ending economic apartheid.

The Nation, September 9: 24-26.

GUERARD, J.B., 1997. Is there a cost to being socially responsible in investing? Journal of Investing, 6(2): 11-18.

JACKSON, W.E., ALESSANDRI, T.M. \& BLACK, S.S., 2005. The price of corporate social responsibility: the case of black economic empowerment transactions in South Africa. Working paper 2005-29, Federal Reserve Bank of Atlanta.

KOOLLEN, J., 2004. BEE: A Strategic View. Empowerment 2004 Black Ownership: Risk of Opportunity. BusinessMap Foundation [Online]. Available at: http://www.bmap.co.za [Accessed 15 November 2005].

KRAMER, L.A., 2001. Alternative methods for robust analysis in event study applications. Advances in Investment Analysis and Portfolio Management, 8: 109-132.

LOCKETT, A., MOON, J. \& VISSER, W., 2006. Corporate social responsibility in management research: focus, nature, salience and sources of influence. Journal of Management Studies, 43(1): 115136.

MAZIBUKO, N.E. \& BOSHOFF, C., 2003. Employee perceptions of share ownership schemes: an empirical study. South African Journal of Business Management, 34(2): 31-44.

McGUIRE, J.B., SUNDGREN, A. \& SCHNEEWEIS, T., 1988. Corporate social responsibility and firm financial performance. Academy of Management Journal, 31(4): 854-872.

McWILLIAMS, A. \& SIEGEL, D., 1997a. The role of money managers in assessing corporate social responsibility research. Journal of Investing, 6(4): 98107.

McWILLIAMS, A. \& SIEGEL, D., 1997b. Event studies in management research. Academy of Management Journal, 40(3): 626-657.

McWILLIAMS, A. \& SIEGEL, D., 2000. Corporate social responsibility and financial performance: correlation or misspecification? Strategic Management
Journal, 21(5): 603-609.

McWILLIAMS, A., SIEGEL, D. \& TEOH, S.H., 1999. Issues in the use of the event study methodology: a critical analysis of corporate social responsibility studies. Organisational Research Methods, 2(2): 340265.

McWILLIAMS, A., SIEGEL, D.S. \& WRIGHT, P.M., 2006. Corporate social responsibility: strategic implications. Journal of Management Studies, 43(1): 1-18.

MEZNAR, M., NIGH, D. \& KWOK, C., 1994. Effect of announcements of withdrawal of South Africa on stockholder wealth. Academy of Management Journal, 37(6): 1663-1684.

MORSING, M. \& SCHULTZ, M., 2006. Corporate social responsibility communication: stakeholder information, response and involvement strategies. Business Ethics: A European Review, 15(4): 323-338. MUNILLA, L.S. \& MILES, M.P., 2005. The corporate social responsibility continuum as a component of stakeholder theory. Business and Society Review, 110(4): 371-387.

ORLITZKY, M., SCHMIDT., F.L. \& RYNES, S.L., 2003. Corporate social and financial performance. Organization Studies, 24(3): 403-441.

POSNIKOFF, J.F., 1997. Disinvestment from South Africa: they did well by doing good. Contemporary Economic Policy, 15(1): 76-86.

REUER, J.J., 2000. Parent firm performance across international joint venture life-cycle stages. Journal of International Business Studies, 31(1): 1-20.

SALINGER, M., 1992. Value event studies. Review of Economics and Statistics, 74(4): 671-677.

SIEGEL, D.S. \& VITALIANO, D.F., 2007. An empirical analysis of the strategic use of corporate social responsibility. Journal of Economics and Management Strategy, 16(3): 773-792.

SOUTHALL, R., 2004. The ANC and black capitalism in South Africa, Review of African Political Economy, 31(100): 313-328.

SOUTHALL, R., 2005. Black empowerment and corporate capital. in Daniel, J. Southall, R. \& Lutchman, J. (Eds). The state of the nation: South Africa 2004-05. Cape Town: HSRC Press.

TEOH, S.W., WELCH, I. \& WAZZAN, C.P., 1999. The effect of socially activist investment policies on the financial markets: evidence from the South African boycott. The Journal of Business, 72(1): 35-89.

THOMPSON, F., 2004. Black economic empowerment in South Africa: the role of parastatals and choices for the restructuring of the electricity industry. Paper presented at the ICS/CAS International Conference 'Looking at South Africa Ten Years on', 10-12 September, London. 
WADDOCK, S.A. \& GRAVES, S.B., 1997. The corporate social performance - financial performance link. Strategic Management Journal, 18(4): 303-319. WINDSOR, D., 2006. Corporate social responsibility: three key approaches. Journal of Management Studies, 43(1): 93-114.

WOOLLEY, R., 2005). Everybody's guide to Black economic empowerment and how to implement it, Cape Town: Zebra Press.

WOOLRIDGE, J.R. \& SNOW, C.C., 1990. Stock market reaction to strategic investment decisions. Strategic Management Journal, 11(5): 353-363.
WORRELL, D.L., DAVIDSON, W.N. \& SHARMA V.M., 1991. Layoff announcements and stockholder wealth. Academy of Management Journal, 34(3): 662678.

WRIGHT, P. \& FERRIS, S.P., 1997. Agency conflict and corporate strategy: the effect of divestment on corporate value. Strategic Management Journal, 18(1): 77-83.

WRIGHT, P., FERRIS, S.P., HILLER, J.S. \& KROLL, M., 1995. Competitiveness through management of diversity: effects on stock price valuation. Academy of Management Journal, 38(1): 272-287. 
Appendix 1

Names of 95 companies and announcement dates of 125 BEE transactions

\begin{tabular}{|c|c|c|c|c|c|}
\hline Name & Date & Name & Date & Name & Date \\
\hline Absa & 06.04 .2004 & Enaleni & 01.11 .2005 & Naspers & 21.04.2004 \\
\hline Absa & 04.07.2006 & $\mathrm{EOH}$ & 16.08.2004 & Nedbank & 19.04.2005 \\
\hline Absa & 25.07.2006 & ERM & 13.06.2003 & Netcare & 23.09.2005 \\
\hline Acucap & 13.02 .2006 & Excell & 19.05.2006 & Netcare & 08.08.2004 \\
\hline Afgri & 24.11.2006 & Exxaro & 13.10.2005 & Netcare & 23.03.2006 \\
\hline AfHarv & 24.02.2002 & Faritec & 30.06 .2005 & Netcare & 01.12 .2004 \\
\hline AlexForb & 15.11.2005 & Firstrand & 04.11 .2004 & Oceana & 26.06.2006 \\
\hline AlexForb & 19.09.2002 & Gijima AST & 07.02 .2006 & OldMutual & 19.04.2005 \\
\hline Angloplats & 19.03.2002 & Glenmib & 13.10 .2005 & Panprop & 11.10.2005 \\
\hline Apex & 09.05.2006 & Gfields & 06.06.2005 & Pergrin & 08.12.2005 \\
\hline ARM & 13.11 .2003 & Gfields & 19.10.2004 & Petmin & 01.02 .2006 \\
\hline Aspen & 31.01 .2002 & Group 5 & 10.08.2005 & Pinnacle & 28.11.2005 \\
\hline Aspen & 17.03.2005 & Hiveld & 23.04 .2006 & PPC & 12.08 .2003 \\
\hline Assore & 10.11.2005 & Illovo & 11.02.2005 & Primedia & 01.11 .2005 \\
\hline Astrapak & 27.10 .2004 & Imperial & 10.12 .2003 & Primedia & 12.09.2005 \\
\hline Aveng & 24.08 .2004 & Imperial & 05.04 .2005 & PSG & 26.02 .2004 \\
\hline BasRead & 18.05.2006 & ISA & 29.06.2006 & PSG & 21.09.2003 \\
\hline BasRead & 23.09.2005 & $\mathrm{JCl}$ & 01.07.2002 & PSG & 14.02 .2006 \\
\hline $\mathrm{BCX}$ & 08.06.2006 & Johncom & 01.12 .2004 & RA-Hold & 27.03 .2006 \\
\hline Bidvest & 09.07.2003 & Johnnic & 05.02 .2002 & Rangold & 09.12.2004 \\
\hline BJMH & 03.08 .2003 & Johnnic & 05.07.2005 & Resilient & 24.09 .2005 \\
\hline Brait & 08.07.2004 & Johnnic & 05.12 .2005 & Resilient & 08.06.2006 \\
\hline Cadiz & 20.03 .2004 & Johnnic & 12.12 .2005 & Sallies & 28.02 .2006 \\
\hline Capital & 28.07.2004 & Johnnic & 20.04.2005 & Sanlam & 06.10 .2004 \\
\hline Capitec & 13.02.2006 & KGMedia & 03.01.2006 & Sanlam & 05.12 .2003 \\
\hline Capitec & 10.03.2006 & KGMedia & 13.10.2005 & Sappi & 19.04.2006 \\
\hline Capitec & 22.09 .2004 & Kairos & 15.02.2005 & Sasfin & 12.12.2005 \\
\hline Cargo & 05.08 .2003 & KWV-Bel & 10.06.2004 & Schamin & 22.04 .2005 \\
\hline CashBil & 04.11 .2004 & $M \& F$ & 19.04.2005 & Setpoint & 27.05 .2005 \\
\hline Comair & 25.07 .2006 & $M \& R$ & 17.10.2003 & Sqone & 03.02 .2006 \\
\hline Conduit & 16.03.2006 & Medclin & 04.10 .2005 & Stanbank & 16.07.2004 \\
\hline Cullinan & 08.05.2006 & Methold & 18.08.2005 & Sunint & 01.11 .2004 \\
\hline Dcentrix & 18.02.2002 & Methold & 18.06.2004 & Sunint & 07.11 .2005 \\
\hline Delta & 09.06.2005 & MTN Group & 02.04 .2004 & Suprgrp & 15.04.2004 \\
\hline Diamondcp & 18.07.2006 & MTN Group & 27.11 .2002 & Telkom & 05.07.2005 \\
\hline Discovery & 13.09.2005 & MTN Group & 13.05.2003 & Tiwheel & 21.01.2005 \\
\hline Drdgold & 28.07.2005 & MTN Group & 26.07.2006 & Trnshex & 28.02.2002 \\
\hline Drdgold & 13.02.2002 & Mustek & 26.11.2003 & Unitrans & 25.08.2004 \\
\hline Edcon & 17.06.2005 & MvelaRes & 18.07.2006 & Village & 21.06.2006 \\
\hline Elbgroup & 16.03.2006 & MvelaGrp & 11.05 .2004 & Winhold & 02.12 .2005 \\
\hline Emira & 05.06 .2006 & Nampak & 14.08.2003 & Zaptronx & 31.03 .2006 \\
\hline Enaleni & 20.02.2006 & Nampak & 18.08.2005 & & \\
\hline
\end{tabular}

